Madrygal. Revista de Estudios Gallegos

ISSN: 1138-9664

http://dx.doi.org/10.5209/madr.80254

\title{
Carta a Novoneyra
}

Francisco Álvarez Koki

Dende aquel tempo

en que empezamos a soñar,

estabas ti na poesía.

Logo con pasos pequenos,

empezamos a seguir o teu camiño.

Ti eras xa a poesía,

os recantos das cousas ditas en mil nomes.

Nos abriamos o pranto no berce xuvenil

e espertamos.

Abrimos a porta e detrás da néboa,

albiscamos O Courel, e escoitamos a túa palabra rompente.

Agora eu dende lonxe fago como as arañas, e tezo silandeiro unha bágoa dende os rañaceos polo Atlántico, até chegar a Fisterra.

Non sei como agradecerche tantas palabras, que fixeron terra, monte e mar no meu peito. A morte non importa porque sempre queda o son dos recunchos e a memoria faise aire que viaxa pola terra que nos abraza. Até entón Amigo NOVONEYRA, falamos. 